\title{
Different times to perform timed artificial insemination when using a P4/E2/eCG-based protocol in buffalo
}

\section{Nelcio Antonio Tonizza de Carvalho ${ }^{1^{*}}$ (D) Júlia Gleyci Soares de Carvalho ${ }^{2,3}$ José Nélio de Sousa Sales $^{4}$ Rodrigo Caron Macari ${ }^{5}$ Pietro Sampaio Baruselli}

\begin{abstract}
${ }^{1}$ Unidade de Pesquisa e Desenvolvimento de Registro, Centro de Pesquisa de Zootecnia Diversificada, Instituto de Zootecnia, Registro, São Paulo, SP, Brasil. E-mail: nelcio@iz.sp.gov.br. *Corresponding author.

${ }^{2}$ Departamento de Reprodução Animal, Faculdade de Medicina Veterinária e Zootecnia, Universidade de São Paulo (USP), São Paulo, SP, Brasil.

${ }^{3}$ Centro de Pesquisa em Urologia, Escola Paulista de Medicina, Universidade Federal de São Paulo (UFSP), São Paulo, SP, Brasil.

${ }^{4}$ Departamento de Medicina Veterinária, Universidade Federal de Lavras (UFL), Lavras, MG, Brasil.

${ }^{5}$ Fazenda Santa Eliza, Dourado, São Paulo, Brasil.

ABSTRACT: The aim of this study was to evaluate different times for timed artificial insemination (TAI) in buffalo submitted to a P4/E2/ eCG-based protocol. In this study, 204 buffaloes were distributed into one of two groups (TAI56, $n=103$ and TAI64, $n=101)$. At a random stage of the oestrous cycle (Day 0 = D0), in the morning (TAI56, a.m.) or afternoon (TAI64, p.m.), buffaloes received an intravaginal progesterone device (P4; $1.0 \mathrm{~g}$ ) plus EB (2.0 mg i.m.). On D9 a.m. (TAI56) or p.m. (TAI64), the P4 was removed and buffaloes received PGF (0.53 mg i.m. sodium cloprostenol) and eCG (400 IU i.m.). On D10 a.m. (TAI56) or p.m. (TAI64), 24 h after P4 removal, buffaloes were treated with EB (1.0 mg i.m.). Buffaloes from TAI56 and TAI64 were inseminated 56 and 64 h after P4 removal (D11, p.m. and D12, a.m., respectively). Ultrasound examinations were performed on D0 to ascertain ovarian follicular status, at TAI to measure the diameter of the dominant follicle (DF) and D42 for pregnancy diagnosis. The statistical analysis was performed using the GLIMMIX procedure of SAS ${ }^{\circledR}$. There was no difference between TAI56 and TAI64 for the diameter of the DF at TAI and the pregnancy per TAI. It was concluded that TAI 56 or 64 h after P4 removal did not affect fertility in buffaloes submitted to the induction of ovulation with EB. The present research supports that is possible to perform TAI at any time throughout the day in buffalo synchronized during the non-breeding season.

Key words: anoestrous, artificial insemination, oestradiol benzoate, follicle, induction of ovulation.
\end{abstract}

\begin{abstract}
Momentos diferentes para executar a inseminação artificial em tempo fixo
\end{abstract} utilizando o protocolo à base de P4/E2/eCG em búfalas

\begin{abstract}
RESUMO: $O$ objetivo deste estudo foi avaliar diferentes momentos para a realização da IATF em búfalas submetidas a um protocolo à base de P4/E2/eCG. Neste estudo, 204 búfalas foram distribuidas em um de dois grupos (IATF56, $n=103$ e IATF64, $n=101$ ). Em estágio aleatório do ciclo estral (Dia $0=$ D0), pela manhã (IATF56, manhã) ou pela tarde (IATF64, tarde), as búfalas receberam um dispositivo intravaginal de progesterona (P4; 1,0 g) e BE (2,0 mg i.m.). No D9 pela manhã (IATF56) ou pela tarde (IATF64), a P4 foi removida e as búfalas receberam $P G F_{2 a}(0,53 \mathrm{mg}$ i.m. cloprostenol sódico) e eCG (400 UI i.m.). No D10 pela manhã (IATF56) ou pela tarde (IATF64), 24 h após a remoção da P4, as búfalas foram tratadas com BE (1,0 mg i.m.). As búfalas dos grupos IATF56 e IATF64 foram inseminadas 56 e 64 h após a remoção da P4 (D11, pela tarde e D12, pela manhã, respectivamente). Avaliações ultrassonográficas foram realizadas no D0 para verificar o status folicular ovariano, na IATF para medir o diâmetro do folículo dominante (FD) e no D42 para o diagnóstico de gestação. A análise estatística foi realizada utilizando o procedimento GLIMMIX do SAS ${ }^{\circledR}$. Não houve diferença entre os grupos IATF56 e IATF64 no diâmetro do FD na IATF e na prenhez por IATF. Conclui-se que a IATF 56 ou 64 h após a remoção da P4 não afeta a fertilidade de búfalas submetidas à indução da ovulação com BE. A presente pesquisa evidencia que é possível realizar a IATF durante todo o dia em búfalas sincronizadas durante a estação reprodutiva desfavorável.

Palavras-chave: anestro, benzoato de oestradiol, folículo, indução da ovulação, inseminação artificial.
\end{abstract}

\section{INTRODUCTION}

TAI programs are used worldwide to increase reproductive efficiency and to enable genetic improvement in buffalo herds. P4/E2/eCG-based protocols for the synchronization of ovulation and TAI $(\mathrm{P} 4+\mathrm{BE}+\mathrm{PGF} 2 \alpha+$ eCG/GnRH or EB) allow for the use of $\mathrm{AI}$ in buffalo cows and heifers during the breeding and non-breeding seasons (BARUSELLI et al., 2013; CARVALHO et al., 2013; CARVALHO et 
al., 2014; MONTEIRO et al., 2016; CARVALHO et al., 2017; MONTEIRO et al., 2018). Currently, TAI can be used throughout the year with satisfactory ovarian responses and pregnancy outcomes in buffaloes (CARVALHO et al., 2016; CARVALHO et al., 2018). However, adjustments in the protocol and specific hormonal strategies to overcome seasonal anoestrus are necessary and important to permit a continuous enhance of the buffalo dairy and beef industry (CARVALHO et al., 2018).

The use of EB for ovulation induction in buffaloes led to ovulation occurrence $\sim 70$ hours after P4 device removal, close to TAI (64 hours after P4 device removal; (CARVALHO et al., 2017). Studies showed that inseminations should be performed within an optimal range before ovulation (SALES et al., 2015). The optimal AI time for the most desirable rate of fertilization in cattle is between 12 and 24 hours before ovulation (ROELOFS et al., 2006). The AI should occur near the time of ovulation to maximize sperm access to the ovum, but not so late that an aging ovum awaits sperm arrival and capacitation (DALTON et al., 2001). A lower P/AI had been associated with a reduced fertilization rate due to receiving AI close to or after ovulation in cattle (DRANSFIELD et al., 1998; ROELOFS et al., 2005; ROELOFS et al., 2006) and in buffaloes (MONTEIRO et al., 2018). However, an optimal pregnancy rate could be achieved when AI is performed 16.2 (MAATJE et al., 1997), 15.3 (AYRES et al., 2008), 14.7 (SÁ FILHO et al., 2013) and 21.8 (SALES et al., 2015) hours before ovulation in cattle. The aim of the present study was to evaluate different times for the performance of TAI in a $\mathrm{P} 4 / \mathrm{E} 2 / \mathrm{eCG}$-based protocol in buffalo submitted to ovulation induction with oestradiol benzoate (EB) $24 \mathrm{~h}$ after $\mathrm{P} 4$ device removal during the non-breeding season. The hypothesis tested was that TAI performed earlier (56 hours after $\mathrm{P} 4$ device removal, $\sim 14$ hours before ovulation) would promote an optimal range for spermatic capacitation and viability of the oocyte, and increase the pregnancy rate in a $\mathrm{P} 4 / \mathrm{E} 2 / \mathrm{eCG}-$ based protocol in the non-breeding season for buffalo.

\section{MATERIALS AND METHODS}

\section{Animals and management}

The experiment was conducted at Santa Eliza Farm (Dourado, São Paulo, Brazil) during the non-breeding season which coincides with an increase in day length (spring to summer). Lactating crossbred Murrah x Mediterranean buffalo (Bubalus bubalis) cows $(\mathrm{n}=204)$ at $3.2 \pm 0.2$ lactations (mean \pm standard error of the mean), $99.9 \pm 3.7$ days in milk,
$6.7 \pm 0.2$ years old and with a body condition score (BCS) $3.9 \pm 0.1$ (scale $1-5$, where $1=$ very thin and $5=$ very fat) were used. Cows were milked twice a day and had contact with their calves only during milking. Buffaloes grazed tropical grasses and were supplemented with corn silage, chopped sugar cane and a grain mix containing ground corn, soybean meal, citrus pulp, whole cottonseed, minerals and vitamins. Animals had free access to water.

\section{Experimental design}

Buffaloes were distributed according to age, number of births, BCS and ovarian activity in one of two groups (TAI56, $\mathrm{n}=103$ and TAI64, $\mathrm{n}=101$ ). At a random stage of the oestrous cycle (Day 0), in the morning (TAI56) or afternoon (TAI64), buffaloes received an intravaginal progesterone device $(\mathrm{P} 4 ; 1.0$ g; Sincrogest ${ }^{\circledR}$, Ourofino Agronegócio, Brazil) plus EB (2.0 mg i.m.; Sincrodiol ${ }^{\circledR}$, Ourofino Agronegócio). On day 9, in the morning (TAI56) or afternoon (TAI64), the P4 device was removed and buffaloes received an injection of $\mathrm{PGF}_{2 \alpha}(0.53 \mathrm{mg}$ i.m; sodium cloprostenol; Sincrocio ${ }^{\circledR}$, Ourofino Agronegócio) plus eCG (equine chorionic gonadotropin; $400 \mathrm{IU}$ i.m.; SincroeCG ${ }^{\circledR}$, Ourofino Agronegócio). On Day 10 , in the morning (TAI56) or afternoon (TAI64), $24 \mathrm{~h}$ after device removal, buffaloes received EB (1.0 mg i.m). Buffaloes from TAI56 and TAI64 underwent TAI 56 and $64 \mathrm{~h}$ after $\mathrm{P} 4$ device removal (D11, afternoon and D12, morning, respectively; Figure 1). All inseminations were performed by the same technician. Frozen-thawed semen straws from two buffalo bulls of proven fertile were equally distributed between the treatment groups.

\section{Ultrasonographic examinations}

Ovaries were scanned by ultrasonography using a $7.5-\mathrm{MHz}$ linear-array transrectal transducer (Mindray DP-2200Vet; Shenzhen, Guangdong, China). Ovarian ultrasonographic examinations were performed on D0 to ascertain ovarian follicular status, at TAI to measure the diameter of the DF, and D42 for pregnancy diagnosis (Figure 1). The pregnancy per TAI (P/TAI) was defined as the number of pregnant buffalo divided by the total number of buffalo mated by TAI. The detection of an embryonic vesicle with a viable embryo (presence of a heartbeat) was used as an indicator of pregnancy.

\section{Statistical analyses}

Statistical analyses were performed using Statistical Analysis System for Windows-SAS. The variables evaluated were diameter of the dominant 


\section{Group}

TAl 56h



US

US

Group
TAl $64 h$

TAl $64 h$

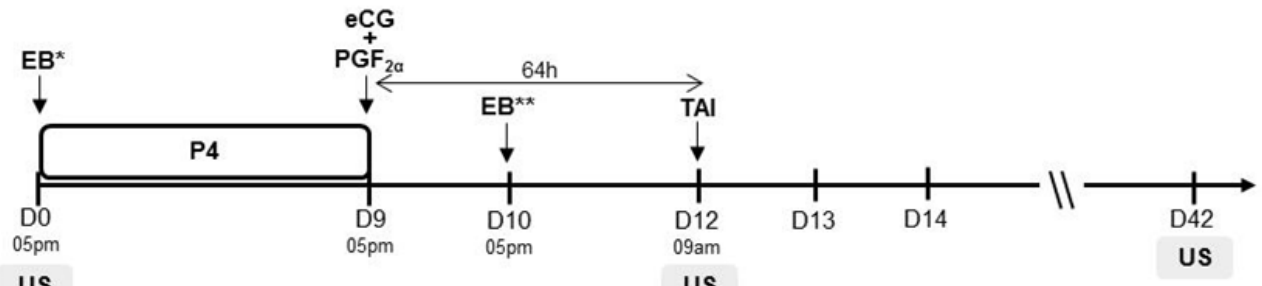

US

US

Figure 1 - Schematic diagram of the treatments for synchronization of ovulation and TAI in buffaloes. $\mathrm{EB}^{*}=2.0 \mathrm{mg}$ oestradiol benzoate; $\mathrm{P} 4=1.0 \mathrm{~g}$ progesterone; $\mathrm{PGF}_{2 \alpha}=0.53 \mathrm{mg}$ sodium cloprostenol; $\mathrm{eCG}=400 \mathrm{IU}$ equine chorionic gonadotropin; $\mathrm{EB}^{* *}=1.0 \mathrm{mg}$ oestradiol benzoate; TAI = timed artificial insemination; US = ultrasonographic examination.

follicle and pregnancy rate. Statistical models created for continuous data were analyzed by Akaike's Information Criterion (AIC) and used the model with lower AIC. Then, the data were analyzed by the GLIMMIX procedure. All values are expressed as mean $\pm \mathrm{SEM}$. The binomial variable $\mathrm{P} / \mathrm{TAI}$ was analyzed using the PROC GLIMMIX procedure of SAS. Explanatory variables such as treatment and BCS at day 0 were included in the model as classes. The model included the fixed effects of treatment, number of births, sire and the random effects of buffaloes. All two-way interactions were tested in logistic regression models. Data were analysed by a multivariate logistic regression using the LOGISTIC procedure of SAS. Variables were removed by backward elimination, based on the Wald statistics criterion when $\mathrm{P}>0.20$ to form the final model. Variables included in the final model for analysis of P/TAI were treatment (TAI56 and TAI64), number of births and BCS at Day 0. The probability curves were obtained using the following formula: $\mathrm{Y}=[\mathrm{EXP}(\operatorname{logit}) / 1+\operatorname{EXP}(\operatorname{logit})]^{*} 100$. Adjusted odds ratio (AOR) and 95\% confidence interval (CI) were generated during the logistic regression. Results are presented as proportions and AOR. The P/TAI was analysed using the GLIMMIX procedure of SAS. Differences with $\mathrm{P} \leq 0.05$ were considered significant and those with $0.05<\mathrm{P} \leq 0.10$ were considered tendencies.

\section{RESULTS}

The diameter of the DF at TAI was similar between treatment groups (TAI56 $=12.9 \pm 0.3$ and TAI64 $=12.5 \pm 0.5 ; \mathrm{P}=0.45)$. However, the diameter of the DF had an effect $(\mathrm{P}=0.02)$ on the P/TAI [diameter $<10.0 \mathrm{~mm}=8.3 \%(1 / 12)^{\mathrm{b}}$; diameter between 10.1 to $12.0 \mathrm{~mm}=26.3 \%(5 / 19)^{\mathrm{b}}$; diameter $>12.1 \mathrm{~mm}$ $\left.65.3 \%(32 / 49)^{\mathrm{a}}\right]$. An increase in the diameter of the DF increased the probability of P/TAI (Figure 2).

There were no significant interactions between treatments for explanatory variables such as BCS $(P=0.79)$ and sire $(P=0.54)$. No differences were reported $(\mathrm{P}=0.88)$ between TAI56 and TAI64 for P/TAI (Figure 3). 


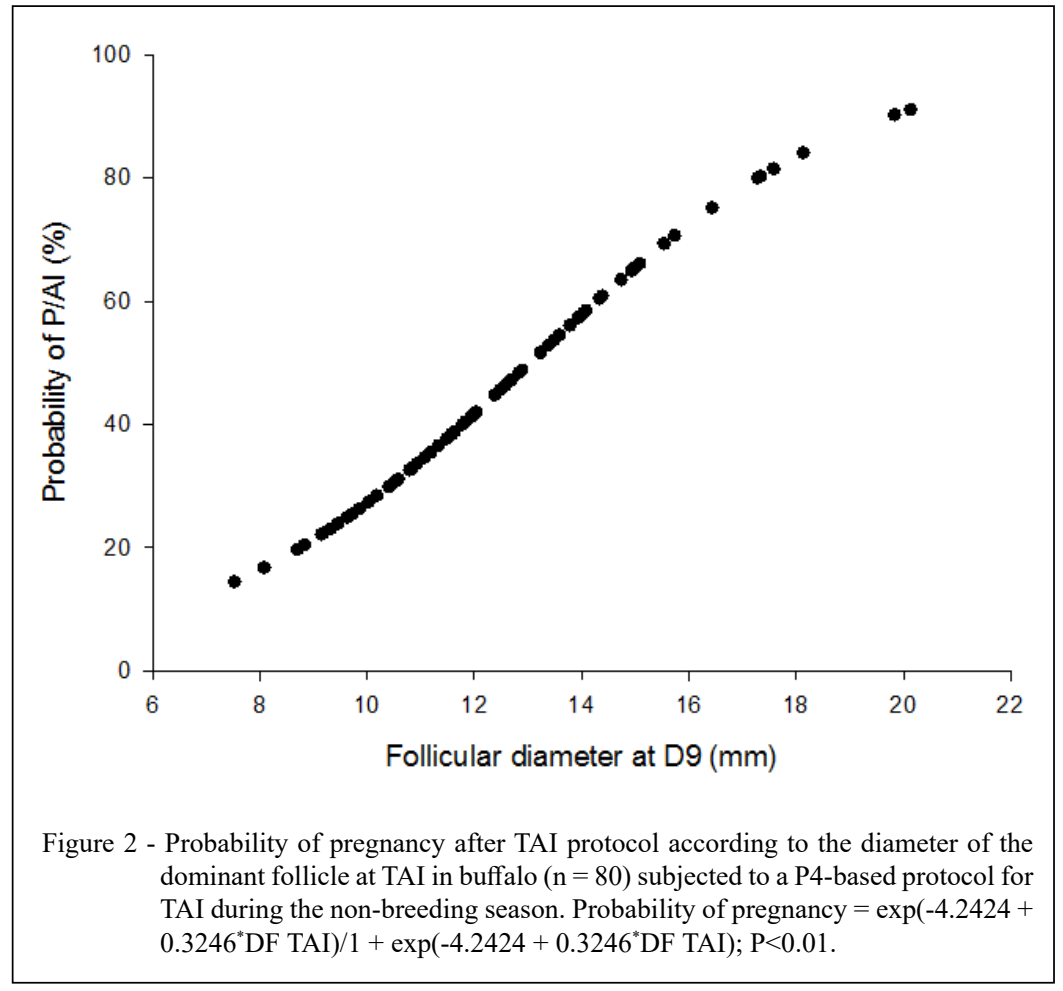

\section{DISCUSSION}

The present study evaluated the flexibility of timing of TAI with regard to the pregnancy rate in buffalo submitted to the induction of ovulation with EB 24 hours after P4 device removal during the nonbreeding season. It was reported that TAI performed 56 and $64 \mathrm{~h}$ after P4 device removal produced similar diameter of the DF at TAI and pregnancy rate. The initial hypothesis of the present study was rejected, since both treatments showed similar P/TAI. Nevertheless, this study provided novel approaches in a $\mathrm{P} 4 / \mathrm{E} 2 / \mathrm{eCG}-$ based protocol in buffalo. Based on these findings, currently is possible to synchronize all the buffaloes in the morning and perform TAI in the afternoon (56 hours) or synchronise all the buffaloes in the afternoon and perform TAI in the morning (64 hours), without compromising fertility. It confers greater flexibility and applicability of the P4/E2/eCGbased protocol in the non-breeding season for buffalo.

The use of EB for synchronizing ovulation in $\mathrm{P} 4 / \mathrm{E} 2 / \mathrm{eCG}$ protocols was previously reported with tight synchrony of ovulation and high fertility, showing a greater pregnancy rate for TAI in buffalo (NASEER et al., 2011; MIRMAHMOUDI et al., 2014; CARVALHO et al., 2017). Other evidence has confirmed EB treatment efficiency for the induction of ovulation in buffalo. Studies have shown that EB treatment induces considerable release of LH (JACOMINI et al., 2014), has a low cost (BARROS et al., 2000; MANES et al., 2012) and maintains high circulating oestradiol concentrations, which likely creates a better uterine environment for embryonic development (BRIDGES et al., 2012).

In the present study, buffalo cows synchronized with EB for ovulation induction had a similar diameter of the DF at TAI between treatment groups. The ovulatory follicle diameter is important in TAI protocols as it is directly related to CL size in buffalo (VECCHIO et al., 2012; CARVALHO et al., 2013; MONTEIRO et al., 2016) and cattle (VASCONCELOS et al., 2001; DADARWAL et al., 2013). A larger CL secretes more P4 (PFEIFER et al., 2009; DADARWAL et al., 2013), which is related to the maintenance of pregnancy and improved fertility in buffalo (VECCHIO et al., 2012) and cattle (BINELLI et al., 2001; INSKEEP, 2004; BARUSELLI et al., 2009; LONERGAN, 2011). The similar diameter of the DF at TAI reported in this study may be associated with the similar P/TAI between treatments.

Although in the present study buffalo cows had similar diameter of the DF at TAI between 


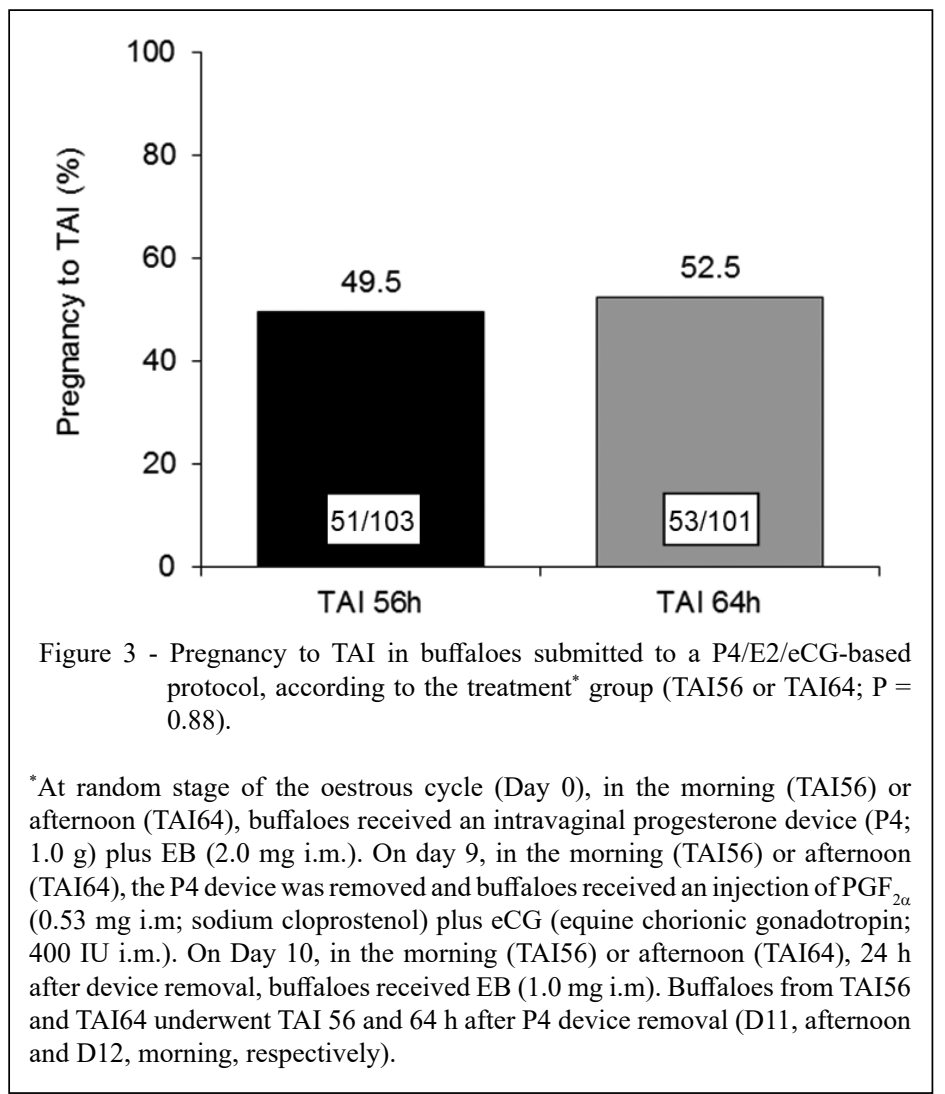

treatment groups, it was verified that the diameter of the DF had an effect on the P/TAI. This result corroborated with a recent study that verified a positive correlation between diameter of the DF at TAI and ovulation and pregnancy rates in buffalo (MONTEIRO et al., 2018) and previous studies performed in cattle (VASCONCELOS et al., 2001; PERRY et al., 2007; SÁ FILHO et al., 2010). Also, it was demonstrated that the diameter of the DF at TAI showed a negative correlation with the occurrence of embryonic mortality in buffaloes (MONTEIRO et al., 2018). Furthermore, MONTEIRO et al. (2016) reported that the development of the synchronization of ovulation protocols for TAI in dairy buffalo should focus on establishing larger and healthy follicles at the end of the synchronization treatment because doing so increases the likelihood of ovulation and pregnancy following TAI.

In the present study, the similar pregnancy rates reported in buffalo that were submitted to different TAI timings during the synchronization protocol showed that the inseminations were performed within an optimal range before ovulation in both treatment groups ( $\sim 6$ to $\sim 14$ hours before ovulation in buffalo, according to (CARVALHO et al., 2017). The optimal time at which insemination should take place relative to ovulation depends primarily on the lifespan of spermatozoa and on the viability of the oocyte in the female genital tract (HUNTER, 1994; AYRES et al., 2008). The sperm require time for capacitation and transport to the oviduct before fertilization (WILTBANK \& PURSLEY, 2014). Previous studies demonstrated that $6 \mathrm{~h}$ is the minimum time needed for a viable sperm population capable of fertilization to pass through the oviduct; the number of progressive motile sperm peaks from 8 to $18 \mathrm{~h}$ after insemination (THIBAULT, 1973; HUNTER \& WILMUT, 1984; HAWK, 1987; AYRES et al., 2008). The most desirable period for oocyte fertilization appears to be between 6 and $10 \mathrm{~h}$ after ovulation (BRACKETT et al., 1980).

\section{CONCLUSION}

The timing of TAI in buffaloes submitted to ovulation induction with EB during the non-breeding season did not change the fertility of these females. The findings of the present study lead to the conclusion 
that is possible to perform TAI throughout the day (morning and afternoon) without compromising fertility in buffalo synchronized in a P4/E2/eCG-based protocol during the non-breeding season.

\section{ACKNOWLEDGEMENTS}

The authors are grateful to Santa Eliza Farm (Dourado, São Paulo, Brazil) for the generous provision of animals and facilities for this study. The research was supported by Ourofino Agronegócio (Cravinhos, SP, Brazil) and FAPESP (Process 2017/50.339-5).

\section{DECLARATION OF CONFLICT OF INTERESTS}

The authors declare no conflict of interest. The founding sponsors had no role in the design of the study; in the collection, analyses, or interpretation of data; in the writing of the manuscript; and in the decision to publish the results.

\section{AUTHOR CONTRIBUTIONS}

All authors contributed equally for the conception and writing of the manuscript. All authors critically revised the manuscript and approved the final version.

\section{REFERENCES}

AYRES, H., et al. Effect of timing of estradiol benzoate administration upon synchronization of ovulation in suckling Nelore cows (Bos indicus) treated with a progesterone-releasing intravaginal device. Animal Reproduction Science, v.109, n.1-4, p.77-87. 2008. Available from: https://pubmed.ncbi.nlm.nih.gov/18242017effect-of-timing-of-estradiol-benzoate-administration-uponsynchronization-of-ovulation-in-suckling-nelore-cows-bosindicus-treated-with-a-progesterone-releasing-intravaginal-device/. Accessed: Sep. 10, 2019. doi: 10.1016/j.anireprosci.2007.12.001.

BARROS, C. M., et al. Synchronization of ovulation in beef cows (Bos indicus) using GnRH, PGF2 $\alpha$ and estradiol benzoate. Theriogenology, v.53, n.5, p.1121-1134. 2000. Available from: $<$ http://linkinghub.elsevier.com/retrieve/pii/S0093691X0000257 0? showall=true $>$. Accessed: Sep. 12, 2019. doi: 10.1016/S0093691X(00)00257-0.

BARUSELLI, P. S., et al. Bovine embryo transfer recipient synchronisation and management in tropical environments. Reproduction, Fertility and Development, v.22, n.1, p.6774. 2009. Available from: <http://www.publish.csiro.au/paper/ RD09214>. Accessed: Sep. 10, 2019. doi: 10.1071/RD09214.

BARUSELLI, P. S., et al. Control of Buffalo Follicular Dynamics for Artificial Insemination, Superovulation and In Vitro Embryo Production. Buffalo Bulletin, v.32, n.Special Issue 1, p.160176. 2013. Available from: <https://www.researchgate.net/ publication/281443261 Control of Buffalo Follicular Dynamics_for_Artificial_Insemination_Superovulation_and_In_ Vitro_Embryo_Production>. Accessed: Sep. 10, 2019.

BINELLI, M., et al. Antiluteolytic strategies to improve fertility in cattle. Theriogenology, v.56, n.9, p.1451-1463. 2001. Available from: <http://linkinghub.elsevier.com/retrieve/pii/S0093691X01 00646X? showall=true $>$. Accessed: Sep. 10, 2019. doi: 10.1016/ S0093-691X(01)00646-X.

BRACKETT, B. G., et al. Fertilization and Early Development of Cow Ova. Biology of Reproduction, v.23, n.1, p.189205. 1980. Available from: <http://www.biolreprod.org/ content/23/1/189.abstract $>$. Accessed: Sep. 12, 2019. doi: 10.1095/ biolreprod23.1.189.

BRIDGES, G. A., et al. Impact of preovulatory estradiol concentrations on conceptus development and uterine gene expression. Animal Reproduction Science, v.133, n.1, p.16-26. 2012. Available from: <http://linkinghub.elsevier.com/retrieve/pii/ S0378432012001893? showall=true $>$. Accessed: Sep. 11, 2019. doi: 10.1016/j.anireprosci.2012.06.013.

CARVAlHO, N. A. T., et al. Strategies to overcome seasonal anestrus in water buffalo. Theriogenology, v.86, n.1, p.200-6. 2016. Available from: <https://www.sciencedirect.com/science/ article/abs/pii/S0093691X16300711>. Accessed: Sep. 10, 2019. doi: 10.1016/j.theriogenology.2016.04.032.

CARVAlHO, N. A. T., et al. Evolution and Perspectives of Timed Artificial Insemination (TAI) Programs in Brazil - A Review. Indian Journal of Animal Reproduction, v.39, n.2, p.1-8. 2018. Available from: <https://www.researchgate.net/ publication/321288864_Indian_Journal_of_Animal_Reproduction_ Issue_December_2018_392>. Āccessed: Sēp. 10, 2019.

CARVALHO, N. A. T., et al. Equine chorionic gonadotropin improves the efficacy of a timed artificial insemination protocol in buffalo during the nonbreeding season. Theriogenology, v.79, n.3, p.423-428. 2013. Available from: <http://www.sciencedirect. com/science/article/pii/S0093691X12005766>. Accessed: Sep. 10, 2019. doi: 10.1016/j.theriogenology.2012.10.013.

CARVALHO, N. A. T., et al. Ovulation synchronization with estradiol benzoate or GnRH in a timed artificial insemination protocol in buffalo cows and heifers during the nonbreeding season. Theriogenology, v.87, p.333-338. 2017. Available from: <https:/www.sciencedirect.com/science/article/abs/pii/ S0093691X16304198>. Accessed: Sep. 10, 2019. doi: 10.1016/j. theriogenology.2016.09.006.

CARVALHO, N. A. T., et al. Different circulating progesterone concentrations during synchronization of ovulation protocol did not affect ovarian follicular and pregnancy responses in seasonal anestrous buffalo cows. Theriogenology, v.81, n.3, p.490-495. 2014. Available from: <http://www.sciencedirect.com/science/ article/pii/S0093691X1300455X>. Accessed: Sep. 10, 2019. doi: 10.1016/j.theriogenology.2013.11.004.

DADARWAL, D., et al. Effect of progesterone concentration and duration of proestrus on fertility in beef cattle after fixed-time artificial insemination. Theriogenology, v.79, n.5, p.859-866. 2013. Available from: <http://www.sciencedirect.com/science/ article/pii/S0093691X13000058>. Accessed: Sep. 11, 2019. doi: 10.1016/j.theriogenology.2013.01.003.

DALTON, J. C., et al. Effect of time of insemination on number of accessory sperm, fertilization rate, and embryo quality in nonlactating dairy cattle. Journal of Dairy Science, v.84, n.11, p.2413-2418. 2001. Available from: <http://linkinghub.elsevier. com/retrieve/pii/S0022030201746905?showall=true>. Accessed: Sep. 11, 2019. doi: 10.3168/jds.S0022-0302(01)74690-5. 
DRANSFIELD, M. B. G., et al. Timing of insemination for dairy cows identified in estrus by a radiotelemetric estrus detection system. Journal of Dairy Science, v.81, n.7, p.1874-1882. 1998. Available from: <https://www.journalofdairyscience.org/article/ S0022-0302(98)75758-3/pdf $>$. Accessed: Sep. 11, 2019.

HAWK, H. W. Transport and fate of spermatozoa after insemination of cattle. Journal of Dairy Science, v.70, n.7, p.1487-1503. 1987. Available from: <http://linkinghub. elsevier.com/retrieve/pii/S002203028780173X?showall=true>. Accessed: Sep. 12, 2019.

HUNTER, R. H.; I. WILMUT. Sperm transport in the cow: peri-ovulatory redistribution of viable cells within the oviduct. Reproduction Nutrition Development, v.24, n.5A, p.597-608. 1984. Available from: <https://hal.archives-ouvertes.fr/hal00898179/document>. Accessed: Sep. 12, 2019.

HUNTER, R. H. F. Causes for failure of fertilization in domestic species. Embryonic Mortality in Domestic Species, p.21. 1994.

INSKEEP, E. K. Preovulatory, postovulatory, and postmaternal recognition effects of concentrations of progesterone on embryonic survival in the cow. Journal of Animal Science, v.82, n.39, p.E24-39. 2004. Available from: <https://pubmed.ncbi.nlm.nih. gov/15471804-preovulatory-postovulatory-and-postmaternalrecognition-effects-of-concentrations-of-progesterone-onembryonic-survival-in-the-cow/>. Accessed: Sep. 10, 2019. doi: 10.2527/2004.8213 supplE24x.

JACOMINI, J. O., et al. LH surge in response to the treatment with GnRH analog or estradiol in ovariectomized buffaloes with or without progesterone pre-exposition. Livestock Science, v.160, p.194-198. 2014. Available from: $<$ https://www.sciencedirect.com/ science/article/abs/pii/S1871141313005106>. Accessed: Sep. 10, 2019. doi: 10.1016/j.livsci.2013.11.017.

LONERGAN, P. Influence of progesterone on oocyte quality and embryo development in cows. Theriogenology, v.76, n.9, p.15941601. 2011. Available from: <https://www.sciencedirect.com/ science/article/abs/pii/S0093691X11002846>. Accessed: Sep. 11, 2019. doi: 10.1016/j.theriogenology.2011.06.012.

MAATJE, K., et al. Predicting Optimal Time of Insemination in Cows that Show Visual Signs of Estrus by Estimating Onset of Estrus with Pedometers. Journal of Dairy Science, v.80, n.6, p.1098-1105. 1997. Available from: <http://www.sciencedirect. com/science/article/pii/S0022030297760351>. Accessed: Sep. 10, 2019. doi: $10.3168 /$ jds.S0022-0302(97)76035-1.

MANES, J., et al. Influence of the Length of Progestagen Treatment and the Time of Oestradiol Benzoate Application on the Ovulatory Follicle Size and Ovulation Time in Anoestrous and Cyclic Beef Cows. Reproduction in Domestic Animals, v.47, n.3, p.412-418. 2012. Available from: $<\mathrm{http}: / / \mathrm{dx}$.doi.org/10 $.1111 / \mathrm{j} .1439-0531.2011 .01890 . \mathrm{x}>$. Accessed: Sep. 10, 2019. doi: 10.1111/j.1439-0531.2011.01890.x.

MIRMAHMOUDI, R., et al. Endocrine changes, timing of ovulation, ovarian follicular growth and efficacy of a novel protocol (Estradoublesynch) for synchronization of ovulation and timed artificial insemination in Murrah buffaloes (Bubalus bubalis). Theriogenology, v.81, n.2, p.237-242. 2014. Available from: <http:// www.sciencedirect.com/science/article/pii/S0093691X13003816>. Accessed: Sep. 10, 2019. doi: 10.1016/j.theriogenology.2013.09.016.
MONTEIRO, B. M., et al. Ovarian responses of dairy buffalo cows to timed artificial insemination protocol, using new or used progesterone devices, during the breeding season (autumn-winter). Animal Science Journal, v.87, n.1, p.13-20. 2016. Available from: $<$ https://pubmed.ncbi.nlm.nih.gov/26032478-ovarian-responses-ofdairy-buffalo-cows-to-timed-artificial-insemination-protocol-usingnew-or-used-progesterone-devices-during-the-breeding-seasonautumn-winter/>. Accessed: Sep. 10, 2019. doi: 10.1111/asj.12400.

MONTEIRO, B. M., et al. Effect of season on dairy buffalo reproductive performance when using $\mathrm{P} 4 / \mathrm{E} 2 / \mathrm{eCG}$-based fixedtime artificial insemination management. Theriogenology, v.119, p.275-281. 2018. Available from: <https://pubmed.ncbi.nlm.nih. gov/30064074-effect-of-season-on-dairy-buffalo-reproductiveperformance-when-using-p4e2ecg-based-fixed-time-artificialinsemination-management/>. Accessed: Sep. 10, 2019. doi: 10.1016/j.theriogenology.2018.07.004

NASEER, Z., et al. Fertility Following CIDR Based Synchronization Regimens in Anoestrous Nili-Ravi Buffaloes. Reproduction in Domestic Animals, v.46, n.5, p.814-817. 2011. Available from: $<$ http://dx.doi.org/10.1111/j.1439-0531.2010.01746.x>. Accessed: Sep. 10, 2019. doi: 10.1111/j.1439-0531.2010.01746.x.

PERRY, G. A., et al. Relationship between size of the ovulatory follicle and pregnancy success in beef heifers. Journal of Animal Science, v.85, n.3, p.684-689. 2007. Available from: $<\mathrm{http} / /$ jas. fass.org/content $/ 85 / 3 / 684$.abstract $>$. Accessed: Sep. 12, 2019. doi: $10.2527 /$ jas.2006-519.

PFEIFER, L. F. M., et al. Effects of low versus physiologic plasma progesterone concentrations on ovarian follicular development and fertility in beef cattle. Theriogenology, v.72, n.9, p.1237-1250. 2009. Available from: <https://pubmed.ncbi. nlm.nih.gov/19781753-effects-of-low-versus-physiologic-plasmaprogesterone-concentrations-on-ovarian-follicular-developmentand-fertility-in-beef-cattle/>. Accessed: Sep. 11, 2019. doi: 10.1016/j.theriogenology.2009.07.019.

ROELOFS, J. B., et al. Effects of insemination-ovulation interval on fertilization rates and embryo characteristics in dairy cattle. Theriogenology, v.66, n.9, p.2173-2181. 2006. Available from: <https://www.sciencedirect.com/science/ article/abs/pii/S0093691X06003876>. Accessed: Sep. 11, 2019. doi: 10.1016/j.theriogenology.2006.07.005.

ROELOFS, J. B., et al. Various behavioral signs of estrous and their relationship with time of ovulation in dairy cattle. Theriogenology, v.63, n.5, p.1366-1377. 2005. Available from: <https://www.sciencedirect.com/science/article/abs/pii/ S0093691X04002456>. Accessed: Sep. 12, 2019. doi: 10.1016/j. theriogenology.2004.07.009.

SÁ FILHO, M. F., et al. Ovarian follicle diameter at timed insemination and estrous response influence likelihood of ovulation and pregnancy after estrous synchronization with progesterone or progestin-based protocols in suckled Bos indicus cows. Animal Reproduction Science, v.120, n.1-4, p.23-30. 2010. Available from: $<\mathrm{https}: / /$ www.sciencedirect.com/science/ article/abs/pii/S0378432010000722>. Accessed: Sep. 10, 2019. doi: 10.1016/j.anireprosci.2010.03.007.

SÁ FILHO, M. F., et al. Timed artificial insemination should be performed early when used norgestomet ear implants are applied for synchronizing ovulation in beef heifers. Theriogenology, v.80, n.6, p.642-647. 2013. Available from: <http://www.sciencedirect. 
com/science/article/pii/S0093691X13002501>. Accessed: Sep. 10, 2019. doi: 10.1016/j.theriogenology.2013.06.008.

SALES, J. N., et al. Effect of circulating progesterone concentration during synchronization for fixed-time artificial insemination on ovulation and fertility in Bos indicus (Nelore) beef cows. Theriogenology, v.83, n.6, p.1093-100. 2015. Available from: $<$ https://pubmed.ncbi.nlm.nih.gov/25619807-effect-of-circulatingprogesterone-concentration-during-synchronization-for-fixed-timeartificial-insemination-on-ovulation-and-fertility-in-bos-indicusnelore-beef-cows/>. Accessed: Sep. 10, 2019. doi: 10.1016/j. theriogenology.2014.12.009.

THIBAULT, C. Sperm transport and storage in vertebrates. Journal of Reproduction and Fertility, v.18, p.15. 1973. Available from: $<$ https://pubmed.ncbi.nlm.nih.gov/4580255-sperm-transport-andstorage-in-vertebrates/>. Accessed: Sep. 12, 2019.

VASCONCELOS, J. L. M., et al. Reduction in size of the ovulatory follicle reduces subsequent luteal size and pregnancy rate. Theriogenology, v.56, n.2, p.307-314. 2001. Available from: <http://www.sciencedirect.com/science/ article/pii/S0093691X01005659>. Accessed: Sep. 10, 2019. doi: 10.1016/S0093-691X(01)00565-9.

VECCHIO, D., et al. Corpus luteum development and function and relationship to pregnancy during the breeding season in the Mediterranean buffalo. Theriogenology, v.77, n.9, p.1811-5. 2012. Available from: <https://pubmed.ncbi.nlm.nih. gov/22365703-corpus-luteum-development-and-function-andrelationship-to-pregnancy-during-the-breeding-season-in-themediterranean-buffalo/>. Accessed: Sep. 11, 2019. doi: 10.1016/j. theriogenology.2011.12.025.

WILTBANK, M. C.; J. R. PURSLEY. The cow as an induced ovulator: Timed AI after synchronization of ovulation. Theriogenology, v.81, n.1, p.170-185. 2014. Available from: $<$ https://www.sciencedirect.com/science/article/abs/pii/ S0093691X13003828>. Accessed: Sep. 10, 2019. doi: 10.1016/j. theriogenology.2013.09.017. 